\title{
Geochemical and Palynological \\ Characteristics in Marginal Sag- Implications on Hydrocarbon Potential, Depositional Environment and Controls on Organic Matter Enrichment
}

\author{
ZIBIN ZHAO ${ }^{1}$ HUIYUAN XU $^{2 *}$ DUJIE HOU ${ }^{1 *}$ \\ XIONG CHENG ${ }^{1}$ CHAO MA $^{3}$ FEILONG WANG ${ }^{4}$ \\ CHANGGUI XU ${ }^{4}$ \\ ${ }^{1}$ School of Energy Resources, China University of \\ Geosciences (Beijing), Beijing 100083, China \\ ${ }^{2}$ Petroleum Exploration \& Production Research Institute, \\ SINOPEC, Beijing 100083, China \\ ${ }^{3}$ Institute of Surface-Earth System Science, Tianjin \\ University, Tianjin 300072, China \\ ${ }^{4}$ Exploration and Development Research Institute, Tianjin \\ branch of CNOOC, Tianjin, 300452, China \\ ${ }^{*}$ Corresponding Author
}

The Northeastern Laizhouwan Sag is a marginal sag in the Bohai Bay Basin in China. Paleogene source rocks, i.e., the third to first member of the Shahejie Formation (Es3, Es2 and $\left.\mathrm{Es}_{1}\right)$, and the third member of the Dongying Formation $\left(\mathrm{Ed}_{3}\right)$ were investigated for their petroleum potential and depositional environment using geochemical and palynological methods. The Es 3 and Es 1 member hold considerable hydrocarbon potential, while the rest are poor. Although varies through wells, the organic matter in the Es3 member is primarily composed by immature-mature type I and II1 kerogen which is primarily contributed by lower aquatic organisms. A saline, stratified and anoxic bottom water prevailed during the Es 3 epoch in the K-a well, while a freshwater and weak reducing condition dominated that in the $\mathrm{K}-\mathrm{b}$ well. The OM in the Es 1 member was contributed more by lower aquatic organisms than the Es2 member, but both are primarily consisted by type $\mathrm{II}_{1}$ and $\mathrm{II}_{2}$ kerogen and, the Es 2 member is maturer than the Es 1 member. A saline and anoxic bottom water prevailed during the Es 2 and Es 1 epoch. The Ed 3 member was contributed more by terrigenous $\mathrm{OM}$ and is dominated by immature type $\mathrm{II}_{2}$ kerogen. A lower salinity and weak reducing depositional condition occurred in the $\mathrm{Ed}_{3}$ member. The OM enrichment of $\mathrm{Es}_{3}$ member was mainly determined by primary productivity and that in the K-a well was also controlled by bottom water condition. The OM accumulation in the other members are speculated to be controlled by deposition rate.

Key Word: depositional environment; oil potential; organic geochemistry; palynology; Bohai Bay Basin; marginal sag. 